DOI: $10.4274 /$ tod. 04796

Turk J Osteoporos 2018;24:59-62

\title{
Pathological Femoral Fracture due to Osteoporosis and Hypophosphatemic Osteomalacia Following Adefovir Therapy in a Patient with Chronic Hepatitis B
}

\author{
Kronik Hepatit B'li Hastada Adefovir Tedavisi Sonrası Gelişen Osteoporoz ve \\ Hipofosfatemik Osteomalaziye Bağlı Patolojik Femur Kırı̆̆ı \\ (D) Sevilay Batıbay, (D) Duygu Geler Külcü, (D) Nilgün Mesci, (D) Borçak Çağlar Ruhi*, (D) Zerrin Şahin, \\ (D) Hasan Gündoğdu** \\ Istanbul Haydarpaşa Numune Training and Research Hospital, Clinic of Physical Medicine and Rehabilitation, Istanbul, Turkey \\ *istanbul Haydarpaşa Numune Training and Research Hospital, Clinic of Nephrology, istanbul, Turkey \\ **Artvin State Hospital, Clinic of Radiology, Artvin, Turkey
}

\section{Abstract}

Adefovir dipivoxil (ADV) is a nucleotide analogue used in the chronic hepatitis B treatment. Proximal renal tubular dysfunction is one of the adverse effects of this agent and characterized with hypophosphatemia and osteomalacia. However, reduced bone mineral density with fracture due to ADV therapy has not been reported before. We aimed to report a 55-year-old male patient with proximal femur fracture who developed hypophosphatemic osteomalacia while using low dose of adefovir (10 mg/day) for chronic hepatitis B treatment for 10 years. Keywords: Adefovir dipivoxil, hypophosphatemia, osteomalacia, osteoporosis, fracture

\section{$\ddot{O z}$}

Adefovir dipivoksil (ADV), kronik hepatit tedavisinde kullanılan bir nükleotid analoğudur. Proksimal renal tübüler fonksiyon bozukluğu, bu ajanın yan etkilerinden biridir ve hipofosfatemi ve osteomalazi ile karakterizedir. Bununla birlikte, ADV tedavisine bağlı kırık ile kemik mineral dansitesinde azalma daha önce bildirilmemiştir. Burada 10 yıldır kronik hepatit B tedavisi için düşük dozda adefovir kullanan (10 mg/gün) 55 yaşındaki erkek hastada hipofosfatemik osteomalazi sonucu gelişen proksimal femur kırı̆̆ı olan bir hastayı bildirmeyi amaçladık. Anahtar kelimeler: Adefovir dipivoksil, hipofosfatemi, osteomalazi, osteoporoz, kırık

\section{Introduction}

Adefovir dipivoxil (ADV) is an adenine dinucleotide analog, used in lamivudine-resistant hepatitis B virus (HBV) infection therapy. Adefovir causes dose-related renal toxicity due to renal tubular dysfunction. Although low-dose ADV therapy (10 mg/day) has been reported to be safe $(1,2)$, there is an increasing number of case reports demonstrating hypophosphatemic osteomalacia caused by proximal renal tubular dysfunction, a feature of Fanconi's syndrome (3-7). However, pathological fractures related to low dose ADV therapy is still uncommon. According to literature, there are two cases with hypophosphatemic osteomalacia and fracture due to low-dose ADV use $(8,9)$. We aimed to present a case with hypophosphatemic osteomalacia caused by Fanconi's syndrome, resulting in osteoporosis and right hip fracture due to low-dose ADV therapy for 10 years.

\section{Case Report}

A 55-year-old man admitted to our clinic with 2-years of bilateral groin pain history referring to anterior thighs exacerbated on weight-bearing. The groin pain gradually increased and he had ambulatory difficulty in the last 3 months. He started to spend most of the his time in the bed. At the time of his admission, he was receiving ADV therapy. He had 18-years of chronic hepatitis history due to HBV infection. He had received lamivudine therapy for 8 years. Since the virus developed resistance to lamivudine, he received ADV $10 \mathrm{mg}$ daily for 10 years. In his locomotor examination; there was a widespread bone tenderness with palpation. Range of motion of hips was limited and painful in all directions, especially on the right side. All lumbar spinous processes and ribs were painful with palpation. The patient was walking antalgic using one cane.

Address for Correspondence/Yazışma Adresi: Sevilay Batıbay MD, İstanbul Haydarpaşa Numune Training and Research Hospital Clinic of Physical Medicine and Rehabilitation, İstanbul, Turkey

Phone: +90 5557035262 E-mail: sevilaycucen@windowslive.com ORCID ID: orcid.org/0000-0002-6286-3632 Received/Geliş Tarihi: 04.07.2017 Accepted/Kabul Tarihi: 08.08.2018

${ }^{\circ}$ Copyright 2018 by the Turkish Osteoporosis Society

Turkish Journal of Osteoporosis published by Galenos Yayınevi. 
He had hypophosphatemia (1.9 mg/dL; normal range, 2.3-4.7 mg/dL) and increased alkaline phosphatase (ALP: 363 IU/L; normal range: $<150 \mathrm{IU} / \mathrm{L}$ ) and serum creatinine (1.79 $\mathrm{mg} / \mathrm{dL}$; normal range: 0.8-1.2 mg/dL) level. Furthermore, he had normal blood urea nitrogen (BUN: $22 \mathrm{mg} / \mathrm{dL}$; normal range: $7-18 \mathrm{mg} / \mathrm{dL}$ ), intact parathyroid hormone (PTH: 41.4 $\mathrm{pg} / \mathrm{mL}$; normal range: 10-65 pg/mL), 25 hydroxyvitamin D (29.2 ng/mL), 1,25-dihydroxyvitamin D3 (24.3 pg/mL; normal range, $16-65 \mathrm{pg} / \mathrm{mL})$, serum glucose $(91 \mathrm{mg} / \mathrm{dL}$ ) and serum calcium $(9.1 \mathrm{mg} / \mathrm{dL}$; normal range: $8.5-10.5 \mathrm{mg} /$ $\mathrm{dL}$ ) levels. Urinalysis revealed proteinuria and glucosuria. A 24-h urine analysis showed increased urinary excretion of phosphate (2070 mg/day; normal range: 400-1300 mg/ day), calcium (586.0 mg/day; normal range: 100-300 mg/ day), hyper micro albuminemia (607.2 mg/day; normal range: 0-30 mg/day), and proteinuria (3.06 g/day; normal range: 0-150 mg/day). Detailed blood sample tests are shown in Table 1. These findings indicated hypophosphatemia and hyperphosphaturia. However, because the patient had normal levels of 25-dihydroxyvitamin D3, we considered that the impaired phosphate reabsorption could have been caused by proximal renal tubule dysfunction.

X-ray graphy was suspicious for right femoral neck fracture. Magnetic resonance imaging (MRI) of right hip joint showed fracture across femoral neck and revealed generalized bone marrow edema around the femoral head and collum which were observed as low intensity on T1-weighted images and high intensity on T2-weighted images and effusion in the hip joint and around the femoral neck (Figure 1a, b).
We examined the bone mineral density (BMD) by dual-X-ray absorptiometry. The BMD was $0.5373 \mathrm{~g} / \mathrm{cm}^{2}$ at femur neck and $0.8573 \mathrm{~g} / \mathrm{cm}^{2}$ at lumbar region. T score was -4.57 at femur neck and -1.65 at L1-L4 lumbar vertebrae. Z score was -2, 98 at femur neck and -1,48 at L1-L4 vertebrae.

On the basis of these findings, we made a diagnosis of osteoporosis, osteomalacia and pathologic fractures due to Fanconi's syndrome secondary to ADV therapy (10 mg/day).

Orthopedic surgeons considered to treat the patient conservatively and follow the patient. The patient was treated conservatively for femoral neck fracture with bed rest and bilateral cane use for daily activities when needed. At the end of 10 months of follow up, a new MRI was issued. The new MRI showed minimal bone marrow oedema at subchondral area of right femoral neck which had low intensity on T1-weighted images and high intensity on T2-weighted images (Figure 1c, d) representing the healing of the fracture.

After diagnosis, ADV was switched with entecavir $1 \mathrm{mg} /$ day and alendronate sodium hydrate $70 \mathrm{mg} 2$ weeks were administered because of the high creatinine clearance levels $(33.2 \mathrm{~mL} / \mathrm{min}$ ) combined with calcium and vitamin D supplementation. After 10 months, we observed that these treatments normalized the blood phosphate $(2.4 \mathrm{mg} / \mathrm{dL})$ and ALP (258 IU/L) levels. Glycosuria resolved and proteinuria reduced significantly. Clinical symptoms such as groin pain and ambulatory difficulty disappeared. He was able to walk without any assistance.

The consent approval of the patient was received.

\section{Table 1. Laboratory examination of the patient}

\begin{tabular}{|c|c|c|}
\hline & Baseline assessment & 10 months follow-up \\
\hline 25 hydroxy vitamin $\mathrm{D}(\mathrm{ng} / \mathrm{mL})$ & 29.2 & 37.5 \\
\hline 1.25 dihydroxy vitamin $\mathrm{D}(\mathrm{pg} / \mathrm{mL})(16-65)$ & 24.3 & 33.9 \\
\hline Alkaline phosphatase (IU/L) $(<150)$ & 363 & 258 \\
\hline Alanine aminotransferase (IU/L) $(<42)$ & 24 & 18 \\
\hline Phosphate (mg/dL) (2.3-4.7) & 1.9 & 2.7 \\
\hline Calcium (mg/dL) (8.5-10.5) & 9.1 & 9.6 \\
\hline Serum glucose $(\mathrm{mg} / \mathrm{dL})$ & 91 & 92 \\
\hline Blood urea nitrogen $(\mathrm{mg} / \mathrm{dL})(7-18)$ & 22 & 19 \\
\hline Creatinine $(\mathrm{mg} / \mathrm{dL})(0.8-1.2)$ & 1.79 & 1.62 \\
\hline Magnesium (mg/dL) (1.6-2.6) & 2.35 & 2.46 \\
\hline Uric acid (mg/dL) (3.5-7.2) & 2.1 & 3.2 \\
\hline Parathyroid hormone $(\mathrm{pg} / \mathrm{mL})(10-65)$ & 41.4 & 49.8 \\
\hline Albumin $(\mathrm{g} / \mathrm{dL})$ & 4.4 & 4.5 \\
\hline Urine examination & $\begin{array}{l}\text { 2+proteinuria, } \\
3+\text { glucosuria }\end{array}$ & $\begin{array}{l}\text { Trace amount of protein, } \\
\text { glucose negative }\end{array}$ \\
\hline Microalbumin excretion/24 hours urine examination (0-30) & $607.2 \mathrm{mg} /$ day & $85.1 \mathrm{mg} /$ day \\
\hline Protein excretion/24 hours urine examination (0-150 mg/day) & $3.06 \mathrm{~g} /$ day & $0.49 \mathrm{~g} /$ day \\
\hline Phosphate excretion/24 hours urine examination (400-1300) & $2070 \mathrm{mg} /$ day & $44.8 \mathrm{mg} /$ day \\
\hline Calcium excretion/24 hours urine examination (100-300) & 586 mg/day & 216 mg/day \\
\hline
\end{tabular}



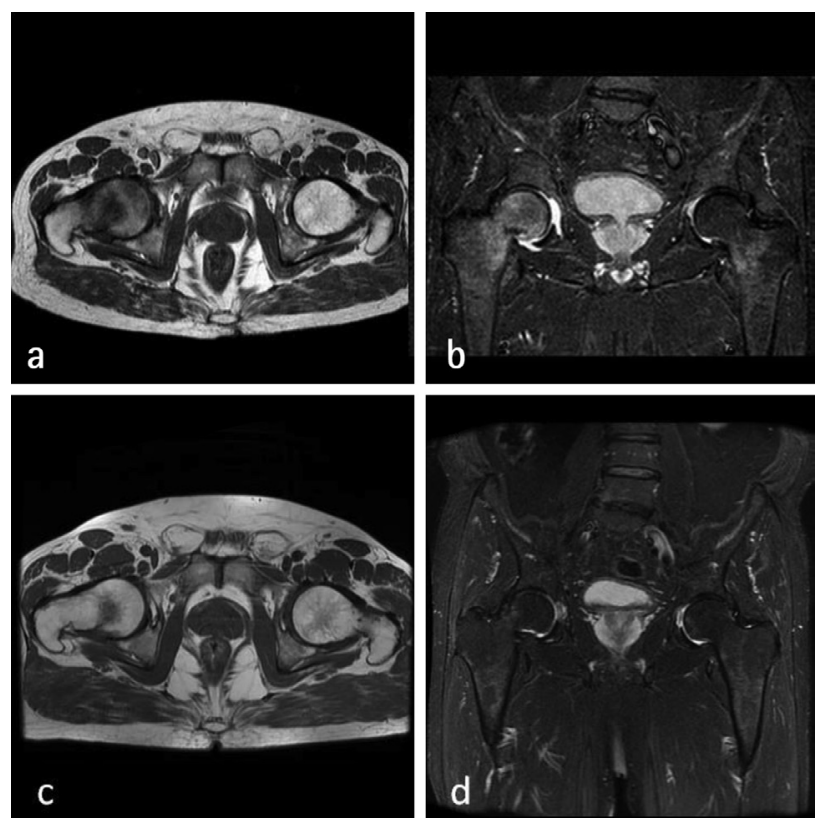

Figure 1. a) Coronal T2W STIR image demonstrating the nondisplaced femoral neck fracture at the right proximal femur medial side, with associated generalized bone marrow oedema at the level of femoral caput and collum. b) Axial T1W images demonstrating fracture line at medial side of the right femoral neck and bone marrow oedema at the level of femoral caput and collum. c) Coronal T2W STIR image demonstrating minimal marrow oedema at subchondral area of right femoral neck posterior side. d) Axial T1W images demonstrating slight bone marrow oedema at subchondral region of right femoral neck posterior side

\section{Discussion}

ADV is a nucleotide analog which is widely used in the treatment of lamivudine-resistant HBV infection. Although it has been reported to be safe $(1,2)$, there is an increasing number of ADV-induced nephrotoxicity reported even at low doses on long-term uses (2-7). Eighteen cases (6 cases in China, 6 cases in Korea, 3 cases in Japan and 1 cases in France, Australia and Italy) have been reported on adefovir induced hypophosphatemic osteomalacia since 2008 (4).

ADV-induced nephrotoxicity is characterized by a decrease in the level of phosphate and a slight increase in creatinine level due to renal proximal tubular dysfunction (10). Adefovir is thought to cause cell necrosis and stop oxidative phosphorylation by inhibiting DNA synthesis in the proximal tubule epithelial cell mitochondria. This renal tubular dysfunction leads to renal phosphate wasting and osteomalacia. Osteomalacia is common in Fanconi's syndrome. Muscle weakness and generalized bone pain are the major symptoms (11). Although pseudo fractures are expected to be seen in osteomalacia, fractures may also be observed in some cases.

Management of ADV-induced osteomalacia includes phosphate supplementation and switching antiviral drug. This management may correct the serum phosphate, ALP and creatinine levels. In our case, the therapy has been switched to entecavir. Dietary phosphate supplementation normalized the serum phosphate levels, reduced the serum ALP and creatinine levels at the end of 10- month follow up. Kim et al. (12) reported a 54-year-old male patientwho had been taking adefovir (10 mg/day) for 59 months due to lamivudine-resistant HBV. Adefovir was replaced with entecavir due to adefovir induced hypophosphatemic osteomalacia. After 8 week phosphate supplementation, symptoms has been improved.

Poh et al. (9), reported a 53-year old patient with multifocal insufficiency fractures including subtrochanteric femoral insufficiency fracture, required surgical fixation, due to ADVinduced hypophosphatemic osteomalacia. The patient received ADV therapy for 59 months. Tanaka et al. (8), reported a 62-year-old man with femoral neck fracture associated with ADV-induced osteomalacia and underwent total hip arthroplasty. The patient had received ADV therapy for 60 months. Our case was 55 year-old man receiving ADV therapy for 120 months. Chen et al. (13) have studied ADV induced hypophosphatemic osteomalacia in Chinese and non Chinese patients and found out that middle aged men are affected more in both groups and its not associated with nationality. Our case was also a 55 year old male supporting the results of Chen et al. (13). We observed right hip fracture and treated the patient conservatively. We noticed that, recent reports did not evaluate the BMD of the patients with fractures. When we evaluated the BMD, we observed severe osteoporosis. According to our literature search, this is the first case presented with osteoporosis and fracture due to ADV therapy for chronic HBV infection. We considered that examining $B M D$ in such patients with fractures is necessary to treat osteoporosis and to avoid potential fractures. Furthermore, we concluded that patients receiving ADV therapy should be monitored for osteoporosis to take precautions before fracture occurs. After diagnosing osteoporosis and fracture, we prescribed alendronate $70 \mathrm{mg}$ every 2 weeks period because of the renal impairment.

Chronic hepatitis B virus (CHB)-associated inflammation could inhibit bone formation and increase bone resorption, leading to a decrease in $\operatorname{BMD}(14,15)$. However, nucleotide analogue (NA) therapies used for CHB treatment also may reduce the BMD. In a study of 319 patients on NA therapy, osteoporosis was present in 19\%, osteopenia in $49 \%$, with an overall $68 \%$ reduction in BMD. Age, gender, and NA therapy were independently associated with reduced BMD (16). Maggi et al. (17) evaluated the patients who treated with lamivudine plus adefovir therapy at the time of switch to tenofovir therapy. They found reduced BMD values in $52.7 \%$ of the patients at baseline especially in femur neck region. Therefore, the patients with $\mathrm{CHB}$, depending on the disease itself or due to the antiviral therapy, seems carrying fracture risk.

In conclusion, physicians prescribing ADV therapy should be aware of the late onset of these complications and should carefully monitor the renal function, phosphate level, bone mineralization and density thus avoid high-risk femur fractures. 


\section{Ethics}

Informed Consent: The patient aproval was received.

Peer-review: Externally peer-reviewed.

\section{Authorship Contributions}

Surgical and Medical Practices: S.B., D.G.K., B.Ç.R., H.G., Concept: S.B., N.M., Z.Ş., Design: S.B., N.M., Z.Ş., Analysis or Interpretation: S.B., H.G., Literature Search: S.B., D.G.K., B.Ç.R., Writing: S.B., D.G.K.

Conflict of Interest: No conflict of interest was declared by the authors.

Financial Disclosure: The authors declared that this study received no financial support.

\section{References}

1. Izzedine H, Hulot JS, Launay-Vacher V, Launay-vacher V, Marcellini P, Hadziyanni SJ, et al. Renal safety of adefovir dipivoxil in patients with chronic hepatitis B: two double-blind, randomized, placebocontrolled studies. Kidney Int 2004;66:1153-8.

2. Fontana RJ. Side effect of long-term oral antiviral therapy for hepatitis B. Hepatology 2009;49(Suppl 5):185-95.

3. Girgis CM, Wong T, Ngu MC, Emmet L, Archer KA, Chen RC, et al. Hypophosphatemic osteomalacia in patients on adefovir dipivoxil. J Clin Gastroenterol 2011;45:468-73.

4. Jeong HJ, Lee JM, Lee JY, Kim HB, Heo MH, Choi MH, et al. Two cases of hypophosphatemic osteomalacia after long-term low dose adefovir therapy in chronic hepatitis $B$ and literature review. J Bone Metab 2014;21:76-83.

5. Jung YK, Yeon JE, Choi JH, Kim CH, Jung ES, Kim JH, et al. Fanconi's syndrome associated with prolonged adefovir dipivoxil therapy in a hepatitis B virus patient. Gut and Liver 2010;4:38993.

6. Eguchi H, Tsuruta M, Tani J, Kuwahara R, Hiromatsu Y Hypophosphatemic osteomalacia due to drug-induced fanconi's syndrome associated with adefovir dipivoxil treatment for hepatitis B. Intern Med 2014;53:233-7.
7. Wu C, Zhang H, Qian Y, Wang L, Gu X, Dai Z. Hypophosphatemic osteomalacia and renal fanconi syndrome induced by low-dose adefovir dipivoxil: a case report and literatüre review suggesting ethnic predisposition. J Clin Pharm Ther 2013;38:321-6.

8. Tanaka M, Setoguchi T, Ishidou $Y$, Arishima $Y$, Hirotsu M, Saitoh $Y$, et al. Pathological femoral fractures due to osteomalacia associated with adefovir dipivoxil treatment for hepatitis B: a case report. Diagn Pathol 2012;7:108.

9. Poh F, Sing BWHS, Mohan PC. Insufficiency fractures related to low-dose adefovir dipivoxil treatment for chronic hepatitis B. Med J Malaysia 2015;1:38-41.

10. Vigano $M$, Lampertico $P$, Colombo M. Drug safety evaluation of adefovir in HBV infection. Expert Opin Drug Saf 2011;10:809-18.

11. Tanji N, Tanji K, Kambham N, Markowitz GS, Bell A, D'agati VD. Adefovir nephrotoxicity: possible role of mitochondrial DNA depletion. Hum Pathol 2001;32:734-40.

12. Kim HD, Sung HD, Min KY. Hypophosphatemic osteomalacia induced by low-dose adefovir therapy: focus on manifestations in the skeletal system and literature review. J Bone Miner Metab 2013;31:240-6.

13. Chen N, Zhang JB, Zhang Q, Zhao YP, Li LY, Liu LW, et al. Adefovir dipivoxil induced hypophosphatemic osteomalacia in chronic hepatitis B: comparative study of Chinese and foreign case series. BMC Pharmacol Toxicol 2018;19:23.

14. Gilbert L, He X, Farmer P, Rubin J, Drissi H, van Wijnen AJ, et al. Expression of the osteoblast differentiation factor RUNX2 ( Cbfa1/AML3/Pebp2alpha A) is inhibited by tumor necrosis factoralpha. J Biol Chem 2002;277:2695-701.

15. Gonzalez-Calvin JL, Gallego-Rojo F, Fernandez-Perez R, CasadoCaballero F, Ruiz-Escolano E, Olivares EG. Osteoporosis, mineral metabolism, and serum soluble tumor necrosis factor receptor p55 in viral cirrhosis. J Clin Endocrinol Metab 2004;89:4325-30.

16. Vigano $M$, Lampertico $P$, Dongiovonni $P$, Facchetti F, Valenti $L$, Soffredini $R$, et al. A drug transporter gene polymorphism predicts renal tubular toxicity in patıents with chronic hepatitis $b$ on long-term adefovir and lamivudine combination. J Hepatology 2010;52:6-7.

17. Maggi P, Montinaro V, Leone A, Fasano M, Volpe A, Bellacosa C, et al. Bone and kidney toxicity induced by nucleotide analogues in patients affected by HBV-related chronic hepatitis: a longitudinal study. J Antimicrob Chemother 2015;70:1150-4. 